\title{
‘Not a Religious State’
}

\section{Al Makin}

To cite this article: Al Makin (2017): 'Not a Religious State', Indonesia and the Malay World, DOI: 10.1080/13639811.2017.1380279

To link to this article: http://dx.doi.org/10.1080/13639811.2017.1380279

\section{Published online: 11 Oct 2017.}

Submit your article to this journal $\pi$

View related articles 주

View Crossmark data $\asymp$ 


\title{
‘NOT A RELIGIOUS STATE' \\ A study of three Indonesian religious leaders on the relation of state and religion
}

\author{
Al Makin \\ Sociology of Religion, Sunan Kalijaga State Islamic University (UIN), Yogyakarta, Indonesia
}

\begin{abstract}
This article explores the concept of a 'secular state' offered by three Indonesian religious leaders: a Catholic priest, Nicolaus Driyarkara (1913-1967), and two Muslim intellectuals who were also state officials, Mukti Ali (1923-2004) and Munawir Sjadzali (1925-2004). All three, who represented the immediate generation after the revolution for Indonesian independence from the Dutch (1945), defended the legitimacy of a secular state for Indonesia based on the state ideology Pancasila (Five Principles of Indonesia). In doing so, they argued that a religious state, for example an Islamic state, is incompatible with a plural nation that has diverse cultures, faiths, and ethnicities. The three also argued that the state should remain neutral about its citizens' faith and should not be dominated by a single religion, i.e. Islam. Instead, the state is obliged to protect all religions embraced by Indonesians. This argument becomes a vital foundation in the establishment of Indonesia's trajectory of unique 'secularisation'. Whilst these three intellectuals opposed the idea of establishing a religious or Islamic state in Indonesia, it was not because they envisioned the decline of the role of religion in politics and the public domain but rather that they regarded religiosity in Indonesia as vital in nation building within a multi-religious society. In particular, the two Muslim leaders used religious legitimacy to sustain the New Order's political stability, and harnessed state authority to modernise the Indonesian Islamic community.
\end{abstract}

\section{KEYWORDS}

Driyarkara; Mukti Ali; Munawir Sjadzali; Islam and Christianity; pluralism; secularisation

\section{Introduction}

Theories and practices of 'secularisation' have been revisited in many studies (Asad 2003; Casanova 1994, 2006; Stark and Iannaccone 1994). The practices of the separation of state and religion are indeed dynamic and never monolithic. Each country may offer different interpretation and policies with regard to the position of religion in national politics (Beckford 2003: 101). For example, France seeks to consistently hold the principle of laïcité, whereas the USA still regards faith in God as an important element in the citizens' patriotism (Stark and Iannaccone 1994). Muslim countries, however, adopt their own policies with regard to positioning Islam in politics. Most of the

CONTACT AI Makin almakin3@gmail.com @ Sunan Kalijaga State Islamic University (UIN), LPPM UIN Sunan Kalijaga Gedung Rektorat Lama 2nd floor Jalan Marsda Adisucipto, Yogyakarta, Indonesia 
Middle Eastern Muslim countries were ruled by military or traditional authoritarian governments, which were later toppled by the Arab Spring movement. Among other Muslim countries, however, the politics of Indonesia can perhaps be compared to that of Turkey (Kersten 2014; Makin 2016b), where secularisation goes hand in hand with nationalism despite the fact that the two countries are dominated by a Muslim population (Barton 2010: 472). Indonesia, with the largest Muslim population in the world, is particularly unique as the majority support secular and nationalist political parties rather than Islamist parties in many general elections (Baswedan 2004; Mujani and Liddle 2009). However, amid the late wave of democratisation in the country, particularly after the fall of Suharto, public piety surged as a consequence of the rise of conservatism and a growing orthodoxy (Barton 2005; Hefner 2000: 84; Makin 2009, 2015, 2016b, 2016c).

It is noteworthy that most Muslim countries in the Middle East are struggling to formulate the position of Islamic religious sentiment in politics. ${ }^{1}$ However, Indonesia since the beginning of its independence in the mid twentieth century, has formulated its own concept of adapting the principles of secularisation with religious faith. Most studies of secularisation in Indonesia have focused on either the earlier period of the struggle for independence, such as Sukarno or M. Natsir (Elson 2009; Ismail 2004; Latif 2011) or later generation intellectuals such as Nurcholish Madjid (1939-2005) or Abdurrachman Wachid (Assyaukanie 2009a, 2009b; Barton 1999, 2010; Kull 2005; Nurdin 2016; Rochmat 2015). This article explores the development of the concept of secularisation proposed by intellectuals immediately after the independence but prior to Madjid. We will also see that Madjid's famous secular slogan 'Islam yes, Islamic party no' was preceded by the ideas of three intellectuals, Nicolaus Driyarkara, Mukti Ali and Munawir Sjadzali, and that we should not directly connect Madjid's ideas to those of early Indonesian leaders such as Sukarno. This article focuses on three prominent religious leaders: Driyarkara, a Catholic priest, and Mukti Ali and Munawir Sjadzali who were Muslim intellectuals and served as Ministers of Religious Affairs under the New Order government. Whilst there has been much written about Mukti Ali and Sjadzali by Indonesian writers (on e.g. Mukti Ali for his ideas and programmes on inter-religious dialogues and Sjadzali, for the contextualisation of Islamic law [figh] in Indonesia), ${ }^{2}$ Driyarkara has received the least attention by scholars within the country and abroad. ${ }^{3}$ Comparing the three will shed light on the parallel ideas these two Muslim thinkers with their Catholic counterpart.

\footnotetext{
${ }^{1}$ Various studies as to why most of the Arab countries struggled to establish democracy from the pre- to post-Arab Spring cover historical, economic, social, theological, and political factors (Diamond et al. 2003). In the aftermath of the Arab Spring, that toppled many Arab authoritarian and militaristic regimes, the democratic movements in the region faced awakening Islamism which prevailed over the waves of democratisation, leading to conflicts in many countries, such as Libya and Syria (Bradley 2012; Pupcenoks 2012). Unsurprisingly, given the more successful transition from Suharto's authoritarian regime to democracy in Indonesia in 1998 than that of the countries during the Arab Spring, there have been efforts to promote Indonesia as a model for other Muslim countries (Hoesterey 2013).

${ }^{2}$ Many Indonesian Muslim scholars have paid attention to Mukti Ali (Basuki 2013; Husin 2014; Ismail 2012; Makin 2012; Munhanif 1996) and Sjadzali (Effendy 1995; Fitria 2012; Gunarto 2007; llyas 2006; Madjid 1995; Sembodo 2005; Tobibatussaadah 2014).

${ }^{3}$ There is a compilation of his works (Driyarkara 2006a) but few have written about him (Haryono and Baryadi 2013; Sutrisno 2000; Ziadi 2013).
} 


\section{Brief biographies of Driyarkara, Mukti Ali and Munawir Sjadzali}

\section{Nicolaus Driyarkara (1913-1967)}

Driyarkara was born on 13 June 1913 in the mountainous area of Menoreh Purworejo, Central Java, and called Soehirman. He was later also known as Djenthu. He went to Volksschool and Vervolgschool in Cangkrep Purworejo and then continued his education at the HIS (Hollandsch Inlandsche School/Dutch-medium elementary school for natives) ${ }^{4}$ in Purworejo and Malang. In 1935, he entered a Catholic seminary in Girisontha, Central Java, and took the name Driyarkara when joining the Jesuit Order (Syarekat Jesuit). Driyarkara also studied philosophy in Muntilan, Central Java, where he learnt Latin and Greek. In 1947 he was ordained as a Catholic priest by Mgr Soegijapranoto, the first Bishop of Semarang. Driyarkara further pursued his theological studies in Maastricht, Netherlands (1949), and Drongen in Belgium, and was awarded a doctorate (1950-1952) at the Pontifical Gregorian University in Rome. His dissertation (1952), 'Theoria participationis in Existentia Dei Percipienda secundum Nicolaum Malebranche' (Embracing the theory of participation in the existence of Nicolas Malebranche) focused on the way one can understand the role of God in the world and human life according to the French philosopher and Oratorian priest, Nicolas Malebranche (1638-1715), whose influence upon later writings by Diryarkara remains visible. On many occasions Driyarkara demonstrated that it is possible to be a rational philosopher, without losing faith in God. ${ }^{5}$ Driyarkara is known for his works dealing with broad interests from ethics, philosophy, education, to Indonesian character building. He taught philosophy and ethics at Ignatius College Yogyakarta and later became the rector of Sanata Dharma Institute of Education (1955-1967). He received a professorship from the University of Indonesia and was visiting professor at the University of St Louis in the US (1963-1964). He also was involved in state administration, serving as a member of the Provisional People's Consultative Assembly (MPRS, Majelis Permusyawaratan Rakyat Sementara) from 1962 to 1967, and of the Supreme Advisory Council (DPA, Dewan Pertimbangan Agung) ${ }^{6}$ from 1965 to 1967 (Danuwinata 2006).

Driyarkara's ideas initially were known only among Indonesian Catholics as he regularly contributed to the column, 'Serat Saking Roma' (Letters from Rome; 1951-1952) in the Javanese-language magazine Praba. His writings discussed in accessible language critical issues ranging from liberalism, communism, poverty, to war victims. On his return to Indonesia, Driyarkara (2006e) carried on writing for Praba with his column, 'Warung Podjok' (Corner Café) under the pen name Pak Nala (1952-1955). In these articles he touched on pertinent topics in Indonesian politics, such as parliamentary issues, democracy, corruption, demonstrations and economic inflation. Driyarkara gained a broader readership when he wrote for the Indonesian-language magazine Basis, ${ }^{7}$ under yet another pen name, Puruhita. His themes in Basis shifted to deeper philosophical reflections. From 1953 to 1965 he served as its editor-in-chief when he was also

\footnotetext{
${ }^{4}$ HIS were established in 1914 under the spirit of Ethical Policy adopted by the Dutch colonialists to improve education.

${ }^{5}$ Nicolas Malebranche was known for combining rationalist Cartesian approaches and those of St Augustine and René Descartes. Malebranche stressed elsewhere the mighty role of God in the world and human affairs, and that it is possible to feel the presence of God through reasoning. In this regard he is also known as belonging to Occasionalism (Driyarkara 2006f: 1385-1452).

${ }^{6}$ DPA abolished in 2003.

${ }^{7}$ Published since 1951.
} 
the dean of education at the Sanata Dharma Institute. Thus his name was known more widely in two fields: philosophy and education. Driyarkara's philosophical reflections mostly present themes on God, nature and human beings, within the context of Indonesia at a critical period of political transition. He was interested in a person's free will and responsibility, and the importance of developing a critical attitude and reflection towards a maturity of human thought (Soedjatmoko 1967). Driyarkara's position as a Catholic priest can be seen in his reflections in which he called upon readers to be closer to God (Hassan 1972). However, his greatest contribution to Indonesia for the purpose of this article is his philosophical reflection on the importance of Pancasila for Indonesia as a nation, and particularly, the role of religion in the country (Danuwinata 2006).

\section{Mukti Ali (1923-2004)}

Mukti Ali was born in 1923 and called Boedjono. He was educated in the Dutch school system and sat for the Klein Ambtenaar Examen (civil service examination). His parents then sent him to a pesantren in Termas, East Java, where he learnt the Qur'an, Arabic, Islamic rituals, jurisprudence, and Sufism. His pesantren teacher, Abdul Hamid, gave him a new name, Mukti Ali. He continued his education at the STI (Sekolah Tinggi Islam, Islamic Higher Education) in Yogyakarta in 1945, which later became UII (Universitas Islam Indonesia, Indonesian Islamic University). At university, Mukti Ali met Muhammdiyah activist Mas Mansur. Thus, Mukti Ali experienced both NU (Nahdlatul Ulama) traditions during his early pesantren education in East Java and the Muhammadiyah environment during his higher education in Yogyakarta. In 1949, he made a pilgrimage to Mecca and went from there to Pakistan to study Islamic history at the Arabic literature department of the University of Karachi. He gained his doctorate in 1955 and proceeded to McGill University for an MA in Islamic Studies in 1957. His varied academic background influenced his interest in comparative religions which he developed in his later career as an intellectual and official under the New Order (Damami et al. 1993). ${ }^{8}$ Mukti Ali started his career as a civil servant in the education section of the Ministry of Religious Affairs, and was lecturer at PTAIN (Perguruan Tinggi Agama Islam Negeri, State Islamic Higher Education) in Yogyakarta and ADIA (Akademi Dinas Ilmu Agama, Academy for Islamic Education) in Jakarta, both of which later became IAINs (Institut Agama Islam Negeri, State Institutes for Islamic Studies). In Jakarta he taught English and served as the secretary of the adab (literature) faculty. However, he was asked to create a new department of comparative religion for the ushuluddin (philosophy and Islamic thought) faculty in IAIN Yogyakarta where he served as the department head. In 1964 he was its vice-rector of academic affairs. His intellectual endeavour developed well in Yogyakarta, as he taught various subjects: sociology and psychology of religions, modern Islamic thought, and contemporary philosophy. His concerns about Islamic high school education was centred on two disadvantages among academics: lack of English skills and the problem of methodology. In response to this, he pioneered a graduate study programme (pascasarjana) in Yogyakarta. Mukti Ali was

${ }^{8}$ For Mukti Ali's biography see e.g. Damami et al. (1993); Dja'far (2006); Husin (2014); Ismail (2012); Makin (2012); Munhanif (1996). 
a prolific writer who also served as the editor-in-chief of the Islamic studies journal $\mathrm{Al}$ Jam'iah in 1964. His writings also appeared in the Syiar Islam and Panji Masyarakat magazines. After the 1965 communist upheaval, he founded a group called Lingkaran Diskusi Limited, holding discussions each Friday night, and attended regularly by Dawam Rahardjo (b.1942), Djohan Effendi (b.1939), and Ahmad Wahib (1942-1973). ${ }^{9}$ The group is widely known for generating liberal and progressive ideas in Islamic intellectual circles in Indonesia. It also invited prominent Indonesian and non-Indonesian scholars, such as Deliar Noer, W.S. Rendra, Lafran Pane, B.J. Boland, Y.W.M Bakker, Niels Mulder, James Peacock, and others. Among Mukti Ali's students in Yogyakarta were Amin Abdullah, Alef Theria Wasim, Burhanuddin Daja, Djama'annuri (Makin 2012). Ali's influence on later generations of Yogyakarta intellectuals can be seen in his students' attitude to religion and Islam. Notable among his students was Amin Abdullah, serving twice as the rector of Sunan Kalijaga State Islamic University Yogyakarta and known for promoting multi-dimensional approaches in the study of Islam. Amin Abdullah also reinterpreted the border between the 'sacred' and 'profane' in Islamic theology (Abdullah 1995, 1996).

In 1971 Mukti Ali was appointed Minister of Religious Affairs. During his tenure, his first attention was to give religious legitimacy to the New Order by promoting 'national development'. For Mukti Ali, development should focus not only on economic or material aspects, but also on the spiritual and religious. Thus, he coined the expression 'material and spiritual development', which served as the ideological foundation of the New Order government. In this regard Mukti Ali served as a bridge connecting the government's interest in national development and Muslim legitimacy to actively participate in it. It is also noteworthy that during Mukti Ali's tenure the MUI (Majelis Ulama Indonesia), the leading Muslim clerical body comprising all Indonesian Muslim groups, was founded in 1975 to support this purpose. His second contribution to the government and Indonesian religious communities was the promotion of inter-religious dialogue, tolerance, and harmony. Mukti Ali also coined the phrase 'agreement in disagreement' (setuju dalam ketidaksetujuan), by which he meant that adherents of different faiths can communicate and cooperate with each other despite differences in beliefs and religious teachings. He also reformed Islamic education by establishing state Islamic high schools (MAN/Madrasah Aliyah Negeri) and giving these the same status as other state high schools which would allow the graduates to continue their education at state universities. Finally, in reforming Islamic education, Mukti Ali gave full support for IAIN lecturers to study abroad in both Western and Middle Eastern universities (Damami et al. 1993: 38-9).

\section{Munawir Sjadzali (1925-2004)}

Munawir Sjadzali was born in Klaten, Central Java, in 1925. Like Mukti Ali, his early education was in various pesantren (Azra and Umam 1998; Feener 2007b: 137; Sjadzali 1995).

\footnotetext{
${ }^{9}$ These three Muslim intellectuals have become symbols of Islamic reformation and liberal ideas in Indonesia, besides Nurcholish Madjid and Abdurrachman Wahid. The three were activists of HMI (Himpunan Mahasiswa Islam/Muslim Students Association) who later promoted an inclusive interpretation of Islam. Rahardjo graduated from economics at the UGM (Gadjah Mada University) and is now rector of Proklamasi University in Yogyakarta. Effendy is an interfaith activist who served as secretary of state during Wahid's presidency. Wahib died at the age of 31 but his book Pergolakan pemikiran Islam (Turmoil of Islamic thought) inspired later generations on various issues from interfaith, inclusive theology, to Islamic reformation.
} 
He completed his elementary education in Solo (1937-1940) and attended the Manba-u al-Ulum madrasah in the same town in 1943. He was involved in the 1945 revolution against the Dutch in Semarang, when he joined the Muslim group Hizbullah dan Sabilillah, and was chosen as the head of the MPHS (Markas Pejuang Hisbullah dan Sabilliah/ Centre of the Army Hizbullah Sabilillah). He was also active in the Islamic Youth Movement (Gerakan Permuda Islam Indonesia, GPII) when an elementary school teacher in Ungaran. His book Mungkinkah negara Indonesia bersendikan Islam (Is an Indonesia based on Islam possible?; 1950) ${ }^{10}$ brought him to the attention of Vice-President Muhammad Hatta and it also paved the way for his diplomatic career at the Ministry of Foreign Affairs. He served as a diplomat to Britain, USA, Sri Lanka, and Kuwait. Munawir Sjadzali pursued further studies at the University of Exeter (1953-1954) in Britain and gained his MA from Georgetown University, USA, with a thesis on 'Indonesia's Muslim parties and their political concepts' (Effendy 1995; Fitria 2012; Ilyas 2006; Sembodo 2005; Tobibatussaadah 2014). His career at the Ministry of Foreign Affairs rose from being a staff member at the Middle Eastern section (1950), to third secretary of the Indonesian embassy in Washington (1956-1959), first secretary of the Indonesian embassy in Colombo (19651968), and finally, as ambassador in the United Arab Emirates (1976-1980). However, the peak of his career was as Minister of Religious Affairs (1983-1993). He also wrote several books on Islam and politics, and on Islamic law in the context of Indonesia (Sjadzali 1995).

Whereas Driyarkara and Mukti Ali started their career as lecturers at religious higher education institutions, Munawir Sjadzali had a long stint in international diplomacy when attached to the Ministry of Foreign Affairs. As with his two counterparts, Munawir Sjadzali showed academic curiosity and was attracted to solving the enigmatic relationship between religion and the state (Prasetyo 1994: 195). In addition, he was attentive to the contextualisation of Islamic law (fiqh) in Indonesia (Fitria 2012; Ilyas 2006; Sembodo 2005; Sjadzali 1988, 1991; Tobibatussaadah 2014) and modernising the Islamic court and education system in Indonesia (Cammack 1997: 162). He deserves credit for improving the quality of the madrasah education system when he was Minister of Religious Affairs (1983-1993) under Suharto as he sought to give the madrasah the same status as state schools under the Ministry of Education. He played a vital role in broadening the academic horizons of Islamic higher education in the country by sending Indonesian lecturers to study at American, Australian, or European universities (Feener 2007a: 278). The alumni of the schools became lecturers at the state Islamic universities, pursued MAs and PhDs in universities within Indonesia and abroad (Aini 2015; Jabali and Jamhari 2003). Munawir Sjadzali can be considered a true heir of Mukti Ali for injecting an Islamic reformation agenda through the government (see, for example, Sjadzali 1984a, 1984b).

Whereas Mukti Ali's tenure was marked by the establishment of the MUI in 1975, Munawir Sjadzali's was marked by the government's effort to curb religious radicalisation by imposing Pancasila upon all movements and organisations in Indonesia as the sole ideology. Between 1982 and 1983 Munawir Sjadzali played a vital and successful role in communicating the government's interest in Islamic organisations, such as NU and Muhammadiyah. Most of the Islamic organisations accepted the government's regulation

\footnotetext{
${ }^{10}$ Sjadzali uses nom de plume Ibn Amatillah M. Sj.
} 
(Sjadzali 1995: 78-82). Interestingly, he also accompanied Suharto on a pilgrimage to Mecca in 1991, in one of the important efforts by Suharto to court Muslim communities in Indonesia to stabilise his regime before stepping down. Since the late 1980s, Islam has emerged again in Indonesian politics as a political issue.

\section{The position of the three intellectuals}

The religious and educational backgrounds of the three intellectuals, Driyarkara, Mukti Ali, and Munawir Sjadzali, bear similarities. They were religious leaders who were trained in both the East and West. They had traditional training in their respective religious foundations, studied theology, and went to the West for further studies. Due to this rich experience and exposure to different cultures and traditions, they, unsurprisingly, showed an open mind and broad perspective in the relationship between state and religion. What is also clear is that all three supported the secular state of Indonesia. With their respective religious authority, the three provided vital ideological support for Suharto's New Order government. All three were involved in state administration. Whereas Driyarkara did not use the state's power to intervene for the Catholic community, Mukti Ali and Munawir Sjadzali used it to modernise Islam - and through both intellectuals Suharto found legitimacy for maintaining power over a Muslim majority country. Mutual benefits can be seen - Suharto enjoyed the support of the two Muslim intellectuals, and they in turn had state support to achieve their reform agenda for the Indonesian Muslim community (Federspiel 1991: 235-9, 1998: 98). Thus, Driyarkara laid a theological foundation for religious people to support the secular state, and Mukti Ali and Munawir Sjadzali served as bridges between the New Order's interest in stabilising national politics, and the reformation of Islam.

It is worth recalling that during the New Order period, relations between Muslims and Christians were some sometimes fraught as each side was suspicious of the other (Makin 2016b). Muslims were fearful that the secularisation agenda was being hijacked by their Christian counterparts for their missionary activities. Similarly, the Christians were afraid that Muslims harboured a clandestine agenda to create an 'Islamic state' (Meuleman 2011: 242; Mujiburrahman 2006). There are similarities in the arguments of Christian and Muslim leaders in the defence of a secular state. In short, the three intellectuals discussed here were religious men who stood on the side of nationalists, albeit from different religious positions. Mukti Ali and Munawir Sjadzali, graduates of pesantren, reformed Islamic modern higher education and its curriculum during their tenure as the Ministers of Religious Affairs (Gunarto 2007: 53-70). The three lived in an era when the formation of Indonesia as both a state and a nation took place at critical stages. The three intellectuals experienced many transitions in the history of the nation: the end of Dutch colonial era, and the Sukarno and Suharto periods. Only Munawir Sjadzali, however, was personally involved in the war for the nation's independence against the Dutch (Sjadzali 1995: 18-42). But all three were involved in the political and religious process during the Sukarno and Suharto periods. It would seem that Mukti Ali and Munawir Sjadzali continued the role of their Christian predecessor in the search to improve relations between the state and religion. Their ideas are important in the study of Indonesian politics and religion because they formulated the relations of religion and state before Nurcholish Madjid, Abdurrachman Wachid, Ahmad Wahib, Dawam Rahardjo, and Djohan Effendi who are 
known for their roles in nurturing secularisation, pluralism, and religious freedom in Indonesia (Barton 1999; Effendy 1995).

\section{Driyarkara: the state should not interfere in the citizens' faith}

In a critical period during which Sukarno sought legitimacy to promulgate Pancasila in Indonesia, Driyarkara defended this state ideology by presenting his philosophical reflection on at a seminar on 'Pancasila' held in Yogyakarta on 17 February 1959. His paper was later translated into English and disseminated to many Indonesian embassies abroad (Driyarkara 1959, 2006b). In it, Driyarkara (2006b: 882; 2006c: 843) highlighted the importance of faith in God by posing Max Scheler's question: Was ist der mensch, und was ist seine Stellung im Sein?' (What is a human being, and what is his or her position in his reality?) For Driyarkara, a human being is more than a combination of body and spirit, but that as an individual he or she is also part of the human collective, based on love and mutual respect. He further stated that in this relationship all human beings deserve decent and equal treatment. In this vein, democratic principles should be established in society. Driyarkara (2006b: 897, 2006c: 844) argued that all men and women, as part of society, must work together since 'democracy is a principle, by which the members (of society) should respect each other, accept others, and work together, based on the common interest. ${ }^{\text {,1 }}$

Driyarkara further expanded that a nation should be built on the principle of the collectivity and consider society's best interest. Society, however, comprises various ethnicities. The establishment of a state should guarantee the prosperity of all citizens equally, regardless of ethnicity and faith. Furthermore, an individual in society should respect other members. All members of society are citizens in a modern state, and should live together as a single entity that encompasses ethnic religious groups (Driyarkara 2006a: 958; 2006c, 846).

As a religious man, Driyarkara stressed the role of God in human life and the way people can reach the Creator by understanding what it means to be a human being, or more specifically, by understanding one's own self. Driyarkara believed that a human being is God's reflection, an understanding commonly held by Christians (based on the Book of Genesis) and Javanese mysticism. In this respect, he recalled the Javanese Serat Wijil: 'He who knows himself knows the most Mighty One who gives life; that is the noble path"12 (Driyarkara 2006c: 848). To approach God, according to Driyarkara, religion is needed as it guides human beings to know his or her existence in the world, towards finding the right path. Referring to the German Jesuit philosopher August Brunner (1894-1985), Driyarkara held that individuals can find the meaning of their existence as a person and as a member of society (Brunner 1956; Driyarkara 2006c: 852). For Driyarkara, the role of religion for people cannot be denied, and were it rejected, other forms of activity similar to that of religion will replace the function of religion (Driyarkara 2006c: 854).

\footnotetext{
${ }^{11}$ Demokrasi adalah prinsip, yang menyebabkan para warga masyarakat saling memandang, menghormati, menerima, dan kerja sama dalam kesatuan sehingga masyarakat dapat bertindak sebagai satu subjek, yang menyelenggarakan kepentingan bersama (Driyarkara 2006c: 844).

${ }^{12}$ In Javanese, 'Sing sapa punika, weruh rekehing sarira, mangka saksat wruh sira maring Yang Widi, iku marga utama.' It is believed that Serat Wijil was originally composed by the East Javanese saint, Sunan Bonang (1465-1525), and was later rewritten by Sultan Hamengkubuwono V (1820-1855). The Serat contains many Javanese Islamic Sufi teaching and can found in the Sonobudoyo museum in Yogyakarta (Apriana 2015).
} 
Driyarkara then related what forms an ideal state and a plural society. Although human beings are religious by nature, as was the case of Driyarkara himself, an individual needs a state in which to live with other individuals, who often embrace different faiths. The state in this respect should guarantee the prosperity of all people regardless of which faith they embrace. Recalling Sukarno's speech in 1945, the essence of Pancasila can be summarised in the principle of gotong royong (cooperation) ${ }^{13}$ (Driyarkara 2006b: 875, 2006c: 859). The term does not refer to a certain form of prayer based on a specific religious teaching, but to cooperation among various people with different faiths (Driyarkara 2006c: 864-5, 2006d: 933). Driyarkara and Sukarno emphasised the nature of secularism in the founding of Indonesia. While religion does make up the Indonesian identity, the separation of religion and state from the beginning of Sukarno's writing is clear (Soekarno 2005a).

Driyarkara often explained that although the state's first principle is belief in One God, it does not mean that all state and citizens' affairs should be based on religious consideration. The state and societal life are basically secular, which he calls 'profane': 'Tetapi janganlah keliru. Dengan ini perbuatannya tidak beralih menjadi kebaktian (But do not be mistaken. With all of this [the first principle of Pancasila], all state affairs do not become religious rituals)' (Driyarkara 2006b: 933). The idea of secularism is revealed in Driyarkara's statement that the state should not interfere in the faith and religion of its people.

Di sini Religi tidak bisa dipaksakan oleh negara sebab Religi berdasarkan keyakinan, dan keyakinan tidak bisa dipaksakan. Oleh sebab itu, negara juga tidak bisa mengatur dan memerintah cara-cara beribadat, bersembahyang, berpuasa, dan sebagainya. Kehidupan Religi tidak masuk dalam tujuan negara yang berlangsung; negara tidak dapat mengurus kebatinan manusia.

Here the state cannot impose a certain religion upon the people, because religion is based on faith and faith cannot be forced. The state therefore should not regulate the way people should pray, perform rites, fast, etc. Religious life is not part of the state's goal, and the state cannot interfere in citizens' spiritual affairs.

(Driyarkara 2006b: 878; 2006c: 862; my translation)

The message seems to refute the idea that the term 'certain religion' refers to 'Islam' as it was clearly stated in the Jakarta charter, with the words, 'perform sharia by Muslims (menjalankan Syariat Islam)' (Elson 2009). Driyarkara's statement delegitimises the possible greater role of Islam in Indonesia, by encompassing other faiths and religions, and not just Islam that is embraced by the majority of Indonesians. Indeed, the debate on the extent of the role of Islam in the political domain in Indonesia continues. Moreover, during Sukarno's period, revolts in the name of Islam against the government did occur, such as the case of Kartosuwiryo (Formichi 2010, 2012). Suharto, however, was tactical in suppressing any possible use of Islam to oppose his power (Temby 2010). After the reform period (reformasi 1998-present), Islamic sentiment remains a potential tool to be exploited in politics, and political Islam and conservatism resurged in this period on the

\footnotetext{
${ }^{13}$ Sukarno proposed the principles of the nation, encapsulated in Pancasila (Five Principles): nationalism, humanity or internationalism, democracy, social welfare, and cooperation (gotong royong). He further states that the most important principle of gotong royong lies 'in an equality between the have and have-not, between Muslims and Christians, and between the native Indonesians and those of foreign descent'. Sukarno did not elaborate on religion or faith, but highlighted the principles of nationalism and unity among diverse Indonesians and emphasising that gotong royong is the most crucial part of Pancasila as it is the essence of all the other principles above (Soekarno 1964; Elson 2009; Latif 2011: 21).
} 
wave of democratisation and openness in Indonesia (Fealy 2004). Driyarkara's statement calling for the state to tolerate all theistic religions in the context of reformasi remains elusive, as the Indonesian government during this period prosecuted many minority groups, such as Lia Eden, Ahmadiyyah, and Syiah (Makin 2016b, 2016c, 2017). Driyarkara's vision of religious freedom and state protection for all faiths, is an idealistic one since the current Indonesian government fails to fulfil this role.

Driyarkara maintained that the state of Indonesia is secular, but it should not stand as the enemy of religion and it is the religious citizens' duty to guard the 'secular' Pancasila. This position reflects the long debate in Indonesia since its independence. Between those who demanded Islam as the official state religion and those who disagreed, a compromise was reached in a rather unique way in that Indonesia neither negates the religiosity of its citizens nor endorses a particular state religion. ${ }^{14}$ Indonesian leaders, such as Sukarno, Hatta, and others, accommodated the factions (Elson 2009). The debate between secularisation and the greater role of religion remains relevant up to reformasi, so that the unique middle path between secularisation and theocracy serves as the best compromise and solution (Budiyono 2014; Latif 2011: 47).

\section{Mukti Ali: stressing only one religious tradition is dangerous}

Like Driyarkara, Mukti Ali emphasised the role of religion in Indonesian society. He chose a pragmatic solution to link religion and the state. Ali (1971: 36-7, 1972, 103-4) felt that Islam, embraced by the majority of Indonesians, was in a position to serve the nation building propagated by the New Order. His views on the spiritual dimensions of people is comparable to that of Driyarkara's since both agreed that the religious faith of citizens is a critical element in building the nation. However, Mukti Ali noted that there are other models of development other than the Western one which lacks spirituality. He emphasised that the larger role of religion inherent in Indonesian cultures and traditions should be drawn on for character building and these should be interpreted more progressively to serve as a driving force for nation building (Ali 1972: 9-10).

Mukti Ali was conscious, however, that what he meant by religion was inclusivity of other religions in the archipelago and did not pertain only to Islam (Husin 2014; Ismail 2012). Additionally, he argued that stressing the dominant role of a single religious tradition, for example Islam, would be detrimental for Indonesian development. For Ali (1972: 20), the co-existence of diverse races, faiths, and languages enriches each other's traditions, and a religious tradition cannot isolate itself from others. Like Driyarkara who stressed the principle of gotong royong, Mukti Ali also reminded Indonesians of the importance of cooperation among diverse faiths and traditions (Steenbrink 1990: 153-9). Mere appreciation of other faiths is insufficient, as trust must be built among all people of different faiths (Ali 1970: 40-1) to achieve national unity. This vital concept of religious pluralism preceded those of Nurcholish Madjid and Abdurrachman Wachid to whom Indonesian studies have paid attention (Barton 1999, 2010; Kull 2005; Makin 2012).

\footnotetext{
${ }^{14}$ Accommodation of various ideas or syncretism is commonly found Indonesian cultures and history. Geertz (1960, 1968), and Hefner (1985) for instance, famously remarked on the intermingling of Javanese local culture and Islam. Soekarno (2005b) is also known for his syncretic ideas of combining nationalism, Islam, and socialism (Yatim 1999).
} 
Whilst Driyarkara states that an individual is part of the human collective, Mukti Ali goes further by stressing that the salvation of one religious group depends on that of others with different faiths. Similarly, the prosperity of one group affects that of others. A single person cannot achieve happiness.

Bangsa Indonesia yang berfalsafah Pancasila ingin membentuk negara kesatuan dengan tidak membenci bangsa lain, yang segala sesuatu ingin dipecahkan secara perembukan dan permusyawaratan, untuk menciptakan suatu masyarakat yang adil dan makmur, yang tindak lakunya selalu mengingat dasar-dasar perikemanusiaan yang beradab, yang didasarkan kepada ke-Tuhanan Yang Maha Esa.

Untuk inilah maka Indonesia baru yang ingin kita bangun itu tidak bisa dibangun oleh sekelompok ummat manusia yang beranggapan bahwa agama yang ia peluk itu harus dipeluk oleh seluruh bangsa Indonesia. Demikian juga Indonesia baru itu tidak bisa dibina oleh sekelompok ummat manusia yang menganggap bahwa agama adalah tidak penting, dan oleh karena itu pembangunan harus dipisahkan dari unsur-unsur agama.

An Indonesian people which has Pancasila as its philosophical foundation aims at establishing a unified nation within which there is no hatred towards other peoples, in which every problem [faced by the nation] should be solved through discussion, in order to achieve a prosperous and just society, in which all [citizens'] conduct should be based on humanity and civilised ethics, with the basis of faith in one God.

To pursue this goal, the new Indonesia we want to build is not founded only by a group of people who assume that their own religion should be embraced by the rest of Indonesians. By the same token, the new Indonesia is not developed by a certain group who assume that religion is not important, so much so that the development programme must be divorced from religious elements.

(Ali 1972: 20; my translation)

Mukti Ali's position resembles that of Driyarkara in supporting the middle path. The first paragraph of the quote above highlights Driyarkara's principle of gotong royong among different faiths. The second paragraph explains the crucial role of religion in the state and supports the New Order's anti-communist propaganda, which has always been associated with atheism, that Indonesians resist (Heryanto 1999; Zurbuchen 2002). Thus, for both Mukti Ali and Driyarkara, Indonesia is not a religious state, but it gives a vital role to religion in the development of the nation.

Both Driyarkara and Mukti Ali have averred in effect that no society can survive without religion (Ali 1971: 6-7) and that religion presents ethical values, according to which individuals can contribute to society in achieving the goal of collective life. Mukti Ali summarised the role of religion in the building of a national character and the need for the state to modernise Islamic education, in accordance with the spirit of progress:

1. Agama adalah dasar azasi bagi etika.

2. Manusia, menurut kodratnya, baik laki-laki maupun wanita, di Indonesia atau ditempat lain, adalah religious.

3. Kepribadian Nasional Indonesia adalah Kepribadian jang ber-Ketuhanan Jang Maha Esa.

4. Adalah suatu keharusan bagi tiap-tiap manusia Indonesia untuk mendjadi pribadi berKetuhanan Jang Maha Esa. 
5. Harus diakui bahwa penjiaran agama Islam, chusunja jang dilakukan dengan djalan pengadjaran dan pendidikan disekolah-sekolah jang teratur, kalu dibandingkan dengan pengdjaran dan pendidikan pengetahuan-pengetahuan lainjja, adalah belum memuaskan.

6. Wanita Indonesia, baik sebagai putri, istri, ibu, maupun sebagai anggota masjarakat umumja, hendaknya berpegang teguh kepada Agamanja masing-msing sebagai sumber dasar etika, dalam membentuk kepribadian Nasional Indonesia.

1. Religion is the basis of ethics.

2. Indonesian men and women are basically religious.

3. The national character is the character of faith in one God.

4. To believe in one God is obligatory for all Indonesian citizens.

5. Religious and particularly Islamic education, when compared with other forms education, is not of a satisfactory standard.

6. Indonesian women, whether unmarried, wives, mothers or other members of society, should hold religion as a source of ethics, an important element for building the national character

(Ali 1971: 14; my translation)

Mukti Ali has argued that a secular Indonesian government, based on Pancasila, does not pose an obstacle for Muslims. Being Muslim and Indonesian is a unique position which can enrich individual spirituality and experience as a citizen of the country. This is in line with Driyarkara's stance in stressing that religious values have been embedded in Indonesian culture and traditions in the form of local customs and norms.

Mukti Ali, a spokesperson of the New Order government bridged the government's interests and the Muslim community. He envisioned that Islam and state could work together to cope with the challenges facing Indonesians, for example, through the educational and legal development programme (pembangunan, reform) in relation to Islam, propagated by the New Order (Dja'far 2006; Meuleman 2011: 159-60). Mukti Ali believed that the government would not be able to implement the programme without the support of Muslims. Likewise, Muslims need government approval, for example, to build mosques, hospitals and pesantren. Only commitment from both sides would ensure the future of the nation.

\section{Munawir Sjadzali: Indonesia is not an Islamic state}

Unlike Mukti Ali who was interested in contemporary issues and the adoption of modern Western approaches in assessing Islam, Munawir Sjadzali turned to classical Arabic sources for understanding Islam. Based on his reading of both classical and modern Arabic works, Munawir Sjadzali believed that Islam is not a political system which was practised by the Prophet Muhammad, the four guided caliphs, and the Umayyad (665750) and Abbasid (750-1517) dynasties (Sjadzali 1990; Effendy 1995; Prasetyo 1994). In line with the works of Husayn Haykal (1888 -1956) and 'Ali 'Abd al-Raziq (18881966), who advocated separation between state and religion, Munawir Sjadzali argued that the Prophet himself did not prescribe a particular form of governmental system. 
Munawir Sjadzali calls for the examination of the way in which the Prophet led the Medinan community in the 7th century (Effendy 1995: 113-16).

Tak lama setelah Nabi menetap di Madinah, atau menurut sementara ahli sejarah belum cukup dua tahun dari kedatangan Nabi di kota itu, beliau mempermaklumkan satu piagam yang mengatur kehidupan dan hubungan antara komunitas-komunitas yang merupakan komponen-komponen masyarakat yang majemuk di Madinah. Piagam tersebut lebih dikenal sebagai Piagam Madinah.

Banyak di antara pemimpin dan pakar ilmu politik Islam beranggapan bahwa Piagam Madinah adalah konstitusi atau undang-undang dasar bagi Negara Islam yang pertama dan yang didirikan oleh Nabi di Madinah.

Not long after the Prophet moved to Medina, or according to many historians after less than two years of the Prophet living in the city, the Prophet declared a charter which regulated the relation between communities, who were the main components of the complex Medinan society. This charter is known as the Medinan charter.

One thing should be noted that the Medina charter, which many experts called the first political charter serving as the first constitution of an Islamic state [does not mention the state's religion].

(Sjadzali 1990: 10; my translation)

The above quotation buttresses the position of both Driyarkara and Mukti Ali in arguing that Indonesia should not be a religious state. Munawir Sjadzali's presentation of the history of Prophet Muhammad's community in Medina aims at convincing Indonesian Muslims that the state's choice in distancing itself from religion is the right decision. Munawir Sjadzali also delegitimises, if not silences, earlier Muslim leaders, such as Natsir, who demanded the greater role of Islam in Indonesian politics (Majid and Roem 1997; Noer 1983; Suhelmi 2002). Munawir Sjadzali highlighted that during the period of the four guided caliphs - Abu Bakr, 'Umar, 'Uthman, and 'Ali b. Abi Talib there was no certain method of appointing the caliphs. Each of the four appointments came about differently, based on a certain component of consensus (shura) among Muslim leaders. However, not every consensus was reached openly, as Abu Bakr was afraid of a possible rupture amongst the Muslim leaders, so the discussion among the elite Companions of the Prophet was closed to the public. However, in the speeches given by the caliphs, Munawir Sjadzali found a kernel of a 'social contract' between the caliphs and the people. The four caliphs however, did not give clear instructions on how to appoint a successor. Tragically, three of the four caliphs were murdered without leaving an indication of who their successors should be. Thus, Munawir Sjadzali also asked Muslims to be aware that Muslim politicians during this period, like current politicians, were political animals who made mistakes and were involved in Machiavellian political manoeuvres (Sjadzali 1990: 234).

The two Muslim dynasties after the four guided caliphs - the Umayyad and Abbasid saw the expansion of Islamic government which went beyond the traditional Arab political system. To Munawir Sjadzali, the influences of non-Arab traditions, for example, that of the Byzantine and Persian, on the governance of these two dynasties are clear.

Mu'awiyah memerintah dari Syam, Damascus sekarang, dekat ibukota Byzantin, Konstantinopel, Istambul sekarang. Dia banyak meminjam pola-pola pemerintahan dari kerajaan Byzantin, termasuk atribut-atribut dan pola hidup raja tetangga itu. 
Mu'awiya (b.Abi Sufyan) ruled (the Muslim community) from Damascus, near Byzantium, Constantinople, nowadays Istanbul. He borrowed some of Byzantine systems of government, including attributes and the rulers' lifestyle. Many formalities, and protocols (that were from Byzantium), were applied.

(Sjadzali 1990: 37; my translation)

Munawir Sjadzali expounded on political theories proposed by many classical Muslim intellectuals such as al-Farabi (872-950), al-Mawardi (972-1058), al-Ghazali (10581111), Ibn Taymiyya (1263-1328), and Ibn Khaldun (1332-1406). He was attracted to theories such as that of al-Farabi concerning the 'virtuous city' (madina fadila) which echoes Greek Platonic philosophy, and that of Al-Mawardi's embryo of a social contract, which he compares to the political theories of Locke and Rousseau. Besides Ibn Khaldun's theories on the birth of society and state, he presented the statement made by Ibn Taymiyya that a just non-Muslim ruler is better than an unjust Muslim ruler (Sjadzali 1990: 110).

Munawir Sjadzali in the above quotation also rejected the Islamist political concept of Abu A'la Mawdudi (1903-1979) and Sayyid Qutb (1906-1966), two ardent proponents that Islam and state are inseparable (Ahmad 2009), a stance taken and contextualised by M. Natsir in Indonesia. Natsir argued that Indonesian unity and nationalism were pioneered by the Islamic spirit, so much so that Indonesian Muslims are bound by duty to implement Islamic rule in the country (Effendy 2003: 21-2). Munawir Sjadzali, however, concluded that:

... bahwa dalam Islam terdapat seperangkat prinsip dan tata nilai etika bagi kehidupan bermasyarakat dan bernegara seperti yang kita temukan dalam Al-Quran, yang memiliki kelenturan dalam pelaksanaan dan penerapannya dengan memperhatikan perbedaan situasi dan kondisi antara satu zaman dengan zaman yang lain serta antara satu budaya dengan budaya yang lain.

Islam contains certain principles and values that guide how to live in a society or state, as found in the Qur'an, but the application, and implementation of these are flexible, depending on differences in the situation and condition from one time period and another, as well as from one culture and another.

(Sjadzali 1990: 236; my translation)

Thus, Munawir Sjadzali felt it unnecessary for Muslims to establish an Islamic state. He called on Indonesian Muslims to accept Pancasila as the state ideology, and particularly, the first of the five principles on the belief in one God, since it does not contradict the teachings of all religions in Indonesia, including Islam. Unlike Mukti Ali whose writing on the separation of state and religion is unclear, Sjadzali formulated more precisely what he meant by Indonesia as a secular state. He opposed the Islamist M. Natsir who argued for an Islamic state for Indonesia. Like Driyarkara, Munawir Sjadzali contended that the current secular state is the best proposition for religious Indonesian citizens.

\section{A unique concept of Indonesian secularisation}

The current debate on secularisation is faced with the fact that an absolute rupture of religion and state is not always relevant (Stark and Iannaccone 1994). Casanova (2006: 7) proposes three characteristics of secularisation: (1) decline of religious belief and practices; (2) privatisation of religion; and (3) differentiation of a secular sphere. However, each country 
gives a unique picture in ways in which the practice of secularisation is dynamic. In France, which is known for upholding the principle of laïcité, the current differentiation of public space and religion needs redefinition, given that popular religions resurged with the adaptation or commodification of religions to fit the secular space (HervieuLéger 1990). However, despite religious revivalism in the past (Anderson 1995), Germany is consistently secular as indicated by the decline of people's religiosity and that of the role of religious institutions (Wolf 2008). The United States, however, draws a different picture in which religiosity and the role of religion cannot be ignored in people's life (Eisgruber 2006). Secularisation and religiosity are in some cases not independent of each other due to a dynamic situation and trends in society; each of the two can relate to, and depend on, the other (Clark and Grandchamp 2011). The growth of religion in modern times can also be seen in South American countries (Becci and Burchardt 2013: 8-9; Casanova 1994). Indonesia, as mentioned, has rather a different trajectory given the distinctive relation of politics and religion in the nation's history.

Driyarkara, Mukti Ali and Munawir Sjadzali, support religious plurality and did not envision the decline of religion in public life or in Indonesia politics. Being religious and holding faith in high regard, they underlined the importance of religion in the public and private lives of Indonesians. While Driyarkara opposed state interference in religious life and considered religion a private matter, Mukti Ali continued to emphasise the role of religion as an ethical guide in political life. Mukti Ali and Munawir Sjadzali would seem not to agree with the complete separation of state from religion. Mukti Ali saw the contribution of religion in the development of the nation and character building particularly in the context of the New Order. During his tenure as a minister under Suharto's government, the MUI was founded and the reformation of Islamic education was initiated. Munawir Sjadzali saw the importance of differentiating between the religious and political spheres, as he rejected the idea of Islam as a political system. For Munawir Sjadzali, Islam provides moral guidance for its adherents but a clearly prescribed political system is not in the Qur'an. He felt that politics is a worldly matter as God has entrusted us with a rational capacity to solve such problems (Effendy 1995; Prasetyo 1994). Munawir Sjadzali continued Mukti Ali's mission to modernise Islamic education and Islamic jurisprudence through state intervention. It was during his tenure as Minister of Religious Affairs that it became mandatory for all religious organisations to adopt the sole state ideology of Pancasila.

Another similarity among the three religious leaders is their patriotic nationalist sentiment; they place national interest and unity before their respective faith. The three hold diversity of religions in Indonesia in high regard. ${ }^{15}$ When Mukti Ali was asked whether he was Indonesian or Muslim, he answered that he was an Indonesian Muslim, a statement by which he meant that Islam still served as his identity (Tibi 1986: 34). Driyarkara, though a Jesuit priest showed his nationalist sentiment clearly, as he regretted that when the independence of the nation was declared on 17 August 1945, he had just arrived in the Netherlands. He could do nothing but condemn the military aggression unleashed by the Dutch after the independence of the nation (Danuwinata 2006: xxvii). Likewise, both

\footnotetext{
${ }^{15}$ In Indonesian scholarship, Nurcholish Madjid and Abdurrachman Wachid have gained the most credit credit for developing the concept of pluralism, whilst earlier proponents like Driyarkara, Mukti Ali, and Munawir Sjadzali have been forgotten.
} 
Mukti Ali and Munawir Sjadzali were ulama ${ }^{16}$ who respected diversity of Indonesia. All three religious figures had further education in the West and had worked for the secular New Order government. Driyarkara and Munawir Sjadzali endorsed Pancasila and rejected the idea of a religious state, whereas Mukti Ali supported a national development scheme and character building in which religion plays a role in the Pancasila state.

Of the three, on the separation of state and religion, it seems that Driyarkara is the only intellectual who consistently held this idea as both concept and praxis. Minority religious groups in Indonesia, such as Catholics, support state secularisation, as in many general elections they mostly voted for secular parties. The two Muslim intellectuals, Mukti Ali and Munawir Sjadzali, did not abide by the principle of separation between state and religion. In practice, the two often used their political power to modernise the Islamic community and to secure the state's interest in curbing radical and conservative ideology, which is on the rise in the current political landscape of Indonesia (Makin 2015, 2016b, 2016c).

Recalling the three aspects of secularisation by Casanova (2006) mentioned earlier, it seems that with Indonesia's choice of a middle path, such a separation of religion and politics will fall short of fulfilment, as religion is ever present in the country's public life. Recent developments after reformasi, has seen a resurgence of religiosity and spirituality (Howell 2001, 2007), as well as Islamic conservatism, radicalism, and orthodoxy (Hefner 2000). Thus, the stance held by Driyarkara, Mukti Ali and Munawir Sjadzali, is even more relevant now as a reminder to Indonesians to return to the middle path (Latif 2011).

The unique concept of secularisation in Indonesia does not deny the role of religion. Mukti Ali and Munawir Sjadzali used their positions as state ministers to modernise the Islamic community, particularly in overhauling and modernising Islamic education in the country. They injected Western curriculum (such as science subjects and pedagogical approaches to religious subjects) in the traditional religious schools (madrasah and pesantren), and encouraged and supported Muslim students and lecturers in Islamic higher education to study at Western universities. The results of their endeavours are evidenced in the enrichment of Indonesian Muslim intellectuals with progressive and liberal ideas (Feener 2007a; Kersten 2015).

Another difference between Driyarkara and the two Muslim intellectuals lies in their religious authority within their respective religious communities (ummah). Driyarkara as a Catholic priest had the whole Catholic community as his audience. However, Mukti Ali and Munawir Sjadzali did not have grassroots connections with the Muslim community. Rather, the two gained authority from the elite educated community in the IAINs/STAINs administered by the Ministry of Religious Affairs (Steenbrink 1990: 153-9). Their intellectual exercise (pembaharuan, reform) was addressed to students and lecturers of these Islamic higher education institutions, whose graduates then brought their progressive ideas to the grassroot level of the ummah in the pesantren, madrasah, and the sub-district level of Islamic courts (KUA). Mukti Ali and Munawir Sjadzali took the opportunity as Ministers of Religious Affairs to work at modernising

\footnotetext{
${ }^{16}$ Mukti Ali was known as a devout Muslim, inculcating similar values and practice in his family and who showed great respect for his his teachers (Damami et al. 1993: 11-12). Similarly, Nurcholish Majdid, a renowned Muslim intellectual, regarded Munawir Sjadzali as a traditional Islamic scholar (kyai) (Madjid 1995).
} 
Islamic education, the Muslim court system, and other fields. Rather than clearly separating state and religious affairs as understood in the concept of secularisation, the New Order brought about educational reforms in Islamic education by improving the quality of teaching, the curricula, and the library (Makin 2000). In fact, the New Order government was not neutral with regard to the affairs of the ummah. If anything, it appears that the government, was on the side of Western-educated Muslim elites whose agenda of modernising the Islamic community coincided with its interest in taming the latent threat of Islamist sentiment. Whilst Islamic radicalism was curbed during the three decades of the New Order, as Islamic authority emanated from the Ministry of Religious Affairs, and the MUI, pluralism in Indonesia is currently under attack by conservative and radical religious factions. The current Indonesian intellectuals need to recall the ideas of earlier leaders who promoted pluralism (Makin 2016a, 2016d, 2016e).

\section{Acknowledgements}

Earlier drafts of this paper was presented at the DAAD (Deutsche Akademische Austauschdienst) alumni meeting in Yogyakarta in December 2010 and at the conference on 'Muslim Religious Authority in Contemporary Asia', Asia Research Institute, National University of Singapore, 24-25 November 2011. I would like to convey my gratitude to Saptoni, Syaifuddin Zuhri, Ain Dewi Utami, and Ratno Lukito at the Al Jamiah research centre of Sunan Kalijaga State Islamic University as well as Michael Feener and Jeremy Kingsly at the Asia Research Institute, Singapore, and the anonymous reviewers of this journal for their constructive feedback. My thanks should also go to Pauline Khng for her generosity and patience in editing my English.

\section{Disclosure statement}

No potential conflict of interest was reported by the author.

\section{Note on contributor}

Al Makin is a senior lecturer at the Sunan Kalijaga State Islamic University Yogyakarta and head of its Research and Community Engagement. His recent publications include Challenging Islamic orthodoxy: accounts of Lia Eden and other prophets in Indonesia (Springer 2016). Email: almakin3@gmail.com

\section{References}

Abdullah, Amin. 1995. Falsafah kalam di era post-modernisme [The philosophy of Islamic theology in the postmodern era]. Yogyakarta: Pustaka Pelajar.

Abdullah, Amin. 1996. Studi agama: normativitas atau historisitas [Religious studies: normativity and historicity]. Yogyakarta: Pustaka Pelajar.

Ahmad, Irfan. 2009. Genealogy of the Islamic state: reflections on Maududi's political thought and Islamism. Journal of the Royal Anthropological Institute 15(1): S145-62.

Aini, Nurul. 2015. Eksistensi MAPK dan pengelolaannya dalam upaya meningkatkan mutu pembelajaran bahasa Arab [The MAPK (Islamic High School of Special Program) and its management in improving Arabic learning and teaching]. MA thesis. Sunan Kalijaga State University, Yogyakarta. <http://digilib.uin-suka.ac.id/17673/1/BAB20I,20V,20DAFTAR20PU STAKA.pdf>

Ali, A. Mukti. 1970. Dialogue between Muslims and Christians in Indonesia and its problems. In Mukti Ali (ed.), Dialog antar agama [Dialogue among religions]. Yogyakarta: Jajasan Nida. 
Ali, A. Mukti. 1971. Etika agama dalam pembentukan kepribadian nasional dan pemberantasan kemaksiatan dari segi agama Islam [Religious ethics in the national character building and eradicating sins from Islamic perspective]. Yogjakarta: Yajasan Nida.

Ali, A. Mukti. 1972. Seni, ilmu, dan agama [Art, knowledge, and religion]. Yogyakarta: Jajasan Nida.

Anderson, Margaret Lavinia. 1995. The limits of secularization: on the problem of the Catholic revival in nineteenth-century Germany. The Historical Journal 38(3): 647-70.

Apriana, R. 2015. Nilai Religiusitas Serat Suluk Wujil Dalam Serat Suluk Warni-Warni Karya Hamengkubuwana V. ADITYA-Pendidikan Bahasa dan Sastra Jawa 7(4): 33-42.

Asad, Talal. 2003. Formations of the secular: Christianity, Islam, modernity. Stanford, CA: Stanford University Press.

Assyaukanie, Luthfi. 2009a. Trajectories of Islamic liberalism in contemporary Indonesia. Journal for the Academic Study of Religion 21(2): 145-74.

Assyaukanie, Luthfi. 2009b. Islam and the secular state in Indonesia. Singapore: ISEAS.

Azra, Azyumardi, and Umam, Saiful. 1998. Menteri-menteri agama RI: biografi sosial-politik. Jakarta: Indonesian-Netherlands Cooperation in Islamic Studies (INIS), Pusat Pengkajian Islam dan Masarakat (PPIM), Ministry of Religious Affairs.

Barton, Greg. 1999. Gagasan Islam liberal di Indonesia: pemikiran neo-modernisme Nurcholis Madjid, Djohan Effendi, Ahmad Wahib dan Abdurrahman Wahid, 1968-1980 [The idea of liberal Islam in Indonesia: the thoughts of neo-modernist Nurcholish Madjid, Djohan Effendi, Ahmad Wahib, and Abdurrachman Wahid]. Jakarta: Paramadina.

Barton, Greg. 2005. Jemaah Islamiyah, radical Islamism in Indonesia. Singapore: Singapore University Press.

Barton, Greg. 2010. Indonesia: legitimacy, secular democracy, and Islam. Politics \& Policy 38(3): 471-96.

Basuki, A. Singgih. 2013. Pemikiran keagamaan A. Mukti Ali [Religious thoughts of A. Mukti Ali]. Yogyakarta: Suka Press.

Baswedan, Anies Rasyid. 2004. Political Islam in Indonesia: present and future trajectory. Asian Survey 44(5): 669-90.

Becci, I. and Burchardt, M. 2013. Religious associations, religious innovations and denominational identities in contemporary global cities. In I. Becci, M. Burchardt and J. Casanova (eds), Topographies of faith religion in urban spaces. Leiden: Brill, pp. 113-128.

Beckford, James A. 2003. Social theory and religion. Cambridge: Cambridge University Press.

Bradley, John R. 2012. After the Arab Spring: how the Islamists hijacked the Middle East revolts. New York: Palgrave Macmillan.

Brunner, August. 1956. Die Religion: eine philosophische Untersuchung auf geschichtlicher Grundlage [Religion: a philosophical investigation from historical perspective]. Freiburg im Breisgau: Herder.

Budiyono. 2014. Hubungan negara dan agama dalam negara Pancasila [The relation of religion and state in Pancasila state]. Fiat Justisia Jurnal Ilmu Hukum 8(3): 410-23.

Cammack, Mark. 1997. Indonesia's 1989 religious judicature act: Islamization of Indonesia or Indonesianization of Islam? Indonesia 63: 143-68.

Casanova, José. 1994. Public religions in the modern world. Chicago: University of Chicago Press.

Casanova, José. 2006. Rethinking secularization: a global comparative perspective. Hedgehog Review 8(1-2): 7-22.

Clark, R. and Grandchamp, D. 2011. Recent trends and anomalies in American secularization. International Review of Modern Sociology 37(1): 91-110.

Damami, M., Nur, S., Aryani, S.A., Mirzanah, S., et al. 1993. H. A. Mukti Ali: ketaatan, kesalehan, dan kecendekiawanan [Religiosity, piety, and intellectualism]. In Abdurrahman, Burhanuddin Daya, and Djam'annuri (eds), Agama dan masyarakat: 70 tahun H.A. Mukti Ali [Religion and society: the 70th anniversary of H.A. Mukti Ali]. Yogyakarta: IAIN Sunan Kalijaga Press, pp. 3-45.

Danuwinata. 2006. Kata pengantar [Preface]. In A. Sudiarja (ed.), Karya lengkap Driyarkara: esaiesai filsafat pemikir yang terlibat penuh dalam perjuangan bangsanya [The complete works of 
Driyarkara: essays on philosophical thoughts in the contribution to the national struggle]. Jakarta: Gramedia Pustaka Utama, pp. xix-xliii.

Diamond, L.J., Plattner, M.F. and Brumberg, D. 2003. Islam and democracy in the Middle East. Baltimore, MD: Johns Hopkins University Press.

Dja'far, Halimah. 2006. Modernisasi keagamaan Islam di Indonesia: telaah pemikiran A Mukti Ali. Kontekstualita, Jurnal Penelitian Sosial Keagamaan 21(2): 22-49.

Driyarkara, N. 1959. Pantja Sila and religion. Jakarta: Ministry of Information.

Driyarkara, N. 2006a. Gambaran manusia Pancasila. In A. Sudiarja, Budi Subanar, St. Sunardi, and T. Sarkim (eds.), Karya lengkap Driyarkara: esai-esai filsafat pemikir yang terlibat penuh dalam perjuangan bangsanya [The complete works of Driyarkara: essays on philosophical thoughts in the contribution to national struggle]. Jakarta: Gramedia Pustaka Utama, pp. 938-972.

Driyarkara, N. 2006b. Kebangkitan Angkatan 66 [The rise of [19]66 generation] or Pemikiran Pancasila sesudah 1965 [Pancasila thought after 1965]. In A. Sudiarja, Budi Subanar, St. Sunardi, and T. Sarkim (eds.), Karya lengkap Driyarkara: esai-esai filsafat pemikir yang terlibat penuh dalam perjuangan bangsanya. Jakarta: Gramedia Pustaka Utama, pp. 867-881.

Driyarkara, N. 2006c. Pancasila dan religi. In A. Sudiarja, Budi Subanar, St. Sunardi, and T. Sarkim (eds.), Karya lengkap Driyarkara: esai-esai filsafat pemikir yang terlibat penuh dalam perjuangan bangsanya. Jakarta: Gramedia Pustaka Utama, pp. 859-866.

Driyarkara, N. 2006d. Pancasila sebagai ideologi. In A. Sudiarja, Budi Subanar, St. Sunardi, and T. Sarkim (eds.), Karya lengkap Driyarkara: esai-esai filsafat pemikir yang terlibat penuh dalam perjuangan bangsanya. Jakarta: Gramedia Pustaka Utama, pp. 911-937.

Driyarkara, N. 2006e. Pendidikan ala Warung Pojok: catatan-catatan Prof. Dr. N. Driyarkara, S.J. tentang masalah sosial, politik, dan budaya [Education in a cafe: notes on Prof. Dr. N. Driyarkara SJ on social, political, and cultural issues]. Edited by Gregorius Budi Subanar and F.X. Danuwinata. Yogyakarta: Penerbit Universitas Sanata Dharma.

Driyarkara, N. 2006f. Apakah menurut Malebranche paham partisipasi berperan dalam pengertian mengenai adanya Allah [What does Malebrance say about the role of participation in the existence of God?]. In A. Sudiarja, Budi Subanar, St. Sunardi, and T. Sarkim (eds.), Karya lengkap Driyarkara: esai-esai filsafat pemikir yang terlibat penuh dalam perjuangan bangsanya. Jakarta: Gramedia Pustaka Utama, pp. 1385-1444.

Effendy, Bahtiar. 1995. Islam and the state in Indonesia: Munawir Sjadzali and the development of a new theological underpinning of political Islam. Studia Islamika: Indonesian Journal for Islamic Studies 2(2): 97-121.

Effendy, Bahtiar. 2003. Islam and the state in Indonesia. Athens, OH: Ohio University Press; Singapore: Institute of Southeast Asian Studies.

Eisgruber, Christopher L. 2006. Secularization, religiosity, and the United States constitution. Indiana Journal of Global Legal Studies 13(2): 445-72.

Elson, R.E. 2009. Another look at the Jakarta Charter controversy of 1945. Indonesia 88: 105-30.

Fealy, Greg. 2004. Islamic radicalism in Indonesia: the faltering revival? In Southeast Asian Affairs. Singapore: Institute of Southeast Asian Studies, pp. 104-21.

Federspiel, Howard M. 1991. Muslim intellectuals and Indonesia's national development. Asian Survey 31(3): 232-46.

Federspiel, Howard. 1998. Islamic values, law and expectations in contemporary Indonesia. Islamic Law and Society 5(1): 90-117.

Feener, R. Michael. 2007a. Cross-cultural contexts of modern Muslim intellectualism. Die Welt Des Islams 47(3-4): 264-82.

Feener, R. Michael. 2007b. Muslim legal thought in modern Indonesia. Cambridge: Cambridge University Press.

Fitria, Vita. 2012. Reaktualisasi hukum Islam: pemikiran Munawir Sjadzali [Reinterpretation of Islamic law: Munawir Sjadzali's thoughts]. Jurnal Akademika 17(2): 1-18.

Formichi, Chiara. 2010. Pan-Islam and religious nationalism: the case of Kartosuwiryo and Negara Islam Indonesia. Indonesia 90: 125-46.

Formichi, Chiara. 2012. Islam and the making of the nation: Kartosuwiryo and political islam in twentieth-century Indonesia. Leiden: KITLV Press. 
Geertz, Clifford. 1960. The religion of Java. Glencoe, IL: Free Press.

Geertz, Clifford. 1968. Islam observed: religions development in Morocco and Indonesia. New Haven, CT: Yale University Press.

Gunarto. 2007. Pemikiran Munawir Sjadzali tentang 'Islam dan negara' dalam perbandingan penafsirannya antara T.B. Simatupang dan Eka Darmaputera dari perspektif kehidupan beragama yang berdasarkan Pancasila [Munawir Sjadzali's thought on Islam and state in comparsion with those of T.B Simatupang and Eka Darmputera from the perspective of religious life based on Pancasila]. STULOS [Journal of Bandung Theological Seminary] 6(1): 53-70.

Haryono, A. and Baryadi, I. Praptomo. 2013. Membaca ulang pemikiran Driyarkara [Re-reading Driyarkara's thoughts]. Yogyakarta: Penerbit Universitas Sanata Dharma.

Hassan, Fuad. 1972. Tjatatan-tjatatan pribadi tentang Prof. Dr. N. Drijarkara, SJ, sebagai pemikir [Personal notes on Prof. Dr. N. Driyarkara as a thinker]. Drijarkara 2(1): 1-15.

Hefner, Robert W. 1985. Hindu Javanese: Tengger tradition and Islam. Princeton, NJ: Princeton University Press.

Hefner, Robert W. 2000. Civil Islam, Muslims and democratization in Indonesia. Princeton, NJ: Princeton University Press.

Hervieu-Léger, Danièle. 1990. Religion and modernity in the French context: for a new approach to secularization. Sociological Analysis 51: S15-S25.

Heryanto, Ariel. 1999. Where communism never dies: violence, trauma and narration in the last Cold War capitalist authoritarian state. International Journal of Cultural Studies 2(2): 147-77.

Hoesterey, James B. 2013. Is Indonesia a model for the Arab Spring? Islam, democracy, and diplomacy. Review of Middle East Studies 47(2): 157-65.

Howell, Julia Day. 2001. Sufism and the Indonesian Islamic revival. The Journal of Asian Studies 60: 701-30.

Howell, Julia Day. 2007. Modernity and Islamic spirituality in Indonesia's new Sufi networks. In M. van Bruinessen and J.D. Howell (eds), Sufism and the 'modern' in Islam. London: I.B. Tauris, pp. 217-40.

Husin, Khairah. 2014. Peran Mukti Ali dalam pengembangan toleransi antar agama di Indonesia [The role of Mukti Ali in developing inter-religious tolerance in Indonesia]. Jurnal Ushuluddin 21(1): 101-20.

Ibn Amatillah, M. Sj. [Munawir Sjadzali]. 1950. Mungkinkah negara Indonesia bersendikan Islam [Is an Indonesia based on Islam possible?]. Semarang: Usaha Taruna.

Ilyas, Yunahar. 2006. Reaktualisasi ajaran Islam: studi atas pemikiran hukum Munawir Sjadzali [Reinterpreting Islamic teachings: A study of Munawir Sjadzali's thougt on law]. Al-Jami'ah: Journal of Islamic Studies 44(1): 223-40.

Ismail, Faisal. 2004. Islam vis-à-vis Pancasila: political tensions and accommodations in Indonesia, 1945-1995. Jakarta: Mitra Cendekia.

Ismail, Faisal. 2012. Paving the way for interreligious dialogue, tolerance, and harmony: following Mukti Ali's path. Al-Jami'ah: Journal of Islamic Studies 50(1): 147-78.

Jabali, Fu'ad and Jamhari (eds). 2003. The modernization of Islam in Indonesia: an impact study on the cooperation between the IAIN and McGill University. Jakarta and Montreal: Indonesia Canada Islamic Higher Education Project. <https://www.mcgill.ca/indonesia-project/files/ indonesia-project/Impact-Study.pdf>

Kersten, Carool. 2014. Urbanization, civil society and religious pluralism in Indonesia and Turkey. In Chiara Formichi (ed.), Religious pluralism, state and society in Asia. London: Routledge, pp. 13-34.

Kersten, Carool. 2015. Islam in Indonesia: the contest for society, ideas and values. Oxford: Oxford University Press.

Kull, Ann. 2005. Piety and politics: Nurcholish Madjid and his interpretation of Islam in modern Indonesia. Lund: Lund University. <http://lup.lub.lu.se/record/25172>

Latif, Yudi. 2011. Negara paripurna: historisitas, rasionalitas, dan aktualitas Pancasila. Jakarta: Gramedia Pustaka Utama.

Madjid, Nurcholish. 1995. Prof. Dr. Munawir Sjadzali, Antara Diplomasi Dan Tugas Kyai [Prof. Dr Munawir Sjadzali, between diplomatic task and another task of religious scholar]. In 
Kontekstualisasi ajaran Islam: 70 tahun Prof. Dr. H. Munawir Sjadzali, M.A. [Contextualizing Islamic teachings: 70 years of Prof. Dr. H. Munawir Sdjazali, MA]. Jakarta: Ikatan Persaudaraan Haji Indonesia and Paramadina, pp. 163-173.

Majid, N. and Roem, M. 1997. Tidak ada negara Islam: surat-surat politik Nurcholish MadjidMohamad Roem [There is no Islamic state: political letters of Nurcholish Madjid and Mohamad Roem]. Edited by Agus Edi Santoso. Jakarta: Djambatan.

Makin, Al. 2000. IAIN and McGill cooperation (10 years: past and future). Yogyakarta: IAIN Indonesian Social Equity Project in Cooperation with the State Islamic University Sunan Kalijaga.

Makin, Al. 2009. Benedict XVI and Islam: Indonesian public reactions to the Regensburg Address. Islam and Christian-Muslim Relations 20(4): 409-21.

Makin, Al. 2012. Pluralism in education, a study of Mukti Ali's thought. In R.A. Curaming and F. Dhont (eds), Education in Indonesia: perspectives, politics and practices. Yogyakarta: Yale Indonesia Forum, Faculty of Social Sciences, Yogyakarta State University, pp. 9-32.

Makin, Al. 2015. Revisiting Indonesian public reactions against Danish cartoons depicting Prophet Muhammad. Indonesian Journal of Islam and Muslim Societies 5(2): 195-229.

Makin, Al. 2016a. Are there any Indonesian philosophers? Dealing with a common question and possible answers. Ulumuna 20(1): 1-28.

Makin, Al. 2016b. Challenging Islamic orthodoxy: the accounts of Lia Eden and other prophets in Indonesia. Dordrecht: Springer.

Makin, Al. 2016c. Islamic Acehnese identity, sharia, and Christianization rumor: a study of the narratives of the attack on the Bethel Church in Penauyong Banda Aceh. Journal of Indonesian Islam 10(1): $1-36$.

Makin, Al. 2016d. Keragaman dan perbedaan, budaya dan agama dalam lintas sejarah manusia [Diversity and difference, culture and religion in human history]. Yogyakarta: Suka Press.

Makin, Al. 2016e. Unearthing Nusantara's concept of religious pluralism: harmonization and syncretism in Hindu-Buddhist and Islamic classical texts. Al-Jami'ah: Journal of Islamic Studies 54 (1): $1-30$.

Makin, Al. 2017. Homogenizing Indonesian Islam: persecution of the Shia group in Yogyakarta. Studia Islamika 24(1): 1-32.

Meuleman, Johan. 2011. Dakwah, competition for authority, and development. Bijdragen Tot de Taal-, Land- En Volkenkunde 167(2-3): 236-69.

Mujani, S. and Liddle, R.W. 2009. Muslim Indonesia's secular democracy. Asian Survey 49(4): 57590.

Mujiburrahman. 2006. Feeling threatened: Muslim-Christian relations in Indonesia's New Order. Amsterdam: Amsterdam University Press.

Munhanif, Ali. 1996. Islam and the struggle for religious pluralism in Indonesia: a political reading of the religious thought of Mukti Ali. Studia Islamika 3(1): 79-126.

Noer, Deliar. 1983. Ideologi, politik dan pembangunan [Ideology, politics, and development]. Jakarta: Yayasan Perkhidmatan.

Nurdin, Ahmad Ali. 2016. Revisiting discourse on Islam and state relation in Indonesia: the view of Soekarno, Natsir and Nurcholish Madjid. Indonesian Journal of Islam and Muslim Societies 6(1): 63-92.

Prasetyo, Hendro. 1994. Pancasila as an Islamic ideology for Indonesian Muslim: an interview with Munawir Sjadzali. Studia Islamika 1(1): 185-205.

Pupcenoks, J. 2012. Democratic Islamization in Pakistan and Turkey: lessons for the post-Arab Spring Muslim world. The Middle East Journal 66(2): 273-89.

Rochmat, Saefur. 2015. The fiqh paradigm for the Pancasila state: Abdurrahman Wahid's thoughts on Islam and the Republic of Indonesia. Al-Jami'ah: Journal of Islamic Studies 52(2): 309-29.

Sembodo, Cipto. 2005. The re-actualization of Islamic law: Munawir Sjadzali and the politics of Islamic legal interpretation under the New Order Indonesia. Al-Jami'ah: Journal of Islamic Studies 43(1): 99-129.

Sjadzali, Munawir. 1984a. Partisipasi umat beragama dalam pembangunan nasional [Muslim community's participation in the national development]. Jakarta: Department of Religious Affairs. 
Sjadzali, Munawir. 1984b. Pendidikan agama dan pengembangan pemikiran keagamaan [Religious education and religious thought development]. Jakarta: Bureau of Law and Public Relations.

Sjadzali, Munawir. 1988. Polemik reaktualisasi ajaran Islam [Polemics on the reinterpretation of Islamic teachings]. Jakarta: Pustaka Panjimas.

Sjadzali, Munawir. 1990. Islam dan tata negara: ajaran, sejarah, dan pemikiran [Islam and state system: teaching, history, and thought]. Jakarta: Penerbit Universitas Indonesia.

Sjadzali, Munawir. 1991. Zakat dan pajak [Almsgiving and tax]. Jakarta: Bina Rena Pariwara.

Sjadzali, Munawir. 1995. Dari lembah kemiskinan [From the valley of poverty]. In M.W. Nafis, B.M. Rachman, E. P. Taher, and A. Wahid (eds), Kontekstualisasi ajaran Islam: 70 tahun Prof. Dr. H. Munawir Sjadzali, M.A. Jakarta: Ikatan Persaudaraan Haji Indonesia: Paramadina, pp. 1-134.

Soedjatmoko. 1967. In memoriam Prof. Dr. N. Dirjarkara. Kompas, 13 February.

Soekarno. 1964. Lahirnya Pantja Sila: pidato pertama tentang Pantja Sila jang diutjapkan pada tg. 1 Djuni 1945 [The birth of Pancasila: the first speech on Pancasila delivered on the 1 June 1945]. Jakarta: Departemen Peneranga.

Soekarno. 2005a. Apa sebab Turki memisah agama dan negara [Why does Turkey separate religion and state]. In Dibawah bendera revolusi [Under the banner of revolution]. Jakarta: Yayasan Bung Karno, pp. 403-47.

Soekarno. 2005b. Nasionalisme, Islamisme, dan Marxisme. In Dibawah Bendera Revolusi. Jakarta: Yayasan Bung Karno, pp. 1-22.

Stark, R. and Iannaccone, L.R. 1994. A supply-side reinterpretation of the 'secularization' of Europe. Journal for the Scientific Study of Religion 33(3): 230-52.

Steenbrink, Karel A. 1990. The study of comparative religion by Indonesian Muslims: a survey. Numen 37(2): 141-67.

Suhelmi, Ahmad. 2002. Polemik negara Islam: Soekarno versus Natsir [Islamic state polemic: Sukarno versus Natsir]. Jakarta: Teraju.

Sutrisno, Mudji. 2000. Driyarkara: dialog-dialog panjang bersama penulis [Driyarkara: long dialogues with the writer]. Jakarta: Obor.

Temby, Quinton. 2010. Imagining an Islamic state in Indonesia: from Darul Islam to Jemaah Islamiyah. Indonesia 89: 1-36.

Tibi, Bassam. 1986. The Iranian revolution and the Arabs: the quest for Islamic identity and the search for an Islamic system of government. Arab Studies Quarterly 8(1): 29-44.

Tobibatussaadah. 2014. Pembaruan pemikiran dalam konteks keindonesiaan: studi terhadap pemikiran hukum Islam Munawir Sjadzali serta pengaruhnya terhadap pemikiran hukum Islam di Indonesia [Renewal of thouhgts in Indonesian context: a study on Munawir Sjadzali's ideas of Islamic law on its impact on the thoughts of Islamic law in Indonesia]. Jurnal Istinbath 11(1): 56-79.

Wolf, Christof. 2008. How secularized Is Germany? Cohort and comparative perspectives. Social Compass 55(2): 111-26.

Yatim, Badri. 1999. Soekarno, Islam, dan nasionalisme [Sukarno, Islam and nationalism]. Ciputat: Logos Wacana Ilmu.

Ziadi, M. Rohman. 2013. Pemikiran ketuhanan Nicolaus Driyarkara, SJ. BA thesis, Sunan Kalijaga State University, Yogyakarta.

Zurbuchen, Mary S. 2002. History, memory, and the '1965 incident' in Indonesia. Asian Survey 42 (4): 564-81. 